Cita bibliográfica: Domareski Ruiz, T. C., Chim Miki, A. F. y Dos Anjos, F. A. (2019). Competitiveness, Economic Legacy and Tourism Impacts: World Cup. Investigaciones Turísticas (17), pp. 49-70. http://dx.doi.org/10.14198/ INTURI2019.17.03

\title{
Competitiveness, Economic Legacy and Tourism Impacts: World Cup
}

\section{Competitividad, Legado Económico e Impacto en el Turismo: Copa del Mundo}

\author{
Thays Cristina Domareski Ruiz, Universidade Federal do Paraná, Brasil. \\ thaysdomareski@gmail.com \\ Adriana Fumi Chim Miki, UFCG - Universidade Federal de Campina Grande, Brasil. \\ adriana.chimmiki@gmail.com \\ Francisco Antonio Dos Anjos, UNIVALI-Universidade do Vale do Itajaí, Brasil. \\ fsanjos@terra.com.br
}

\begin{abstract}
Tourism legacy impacts are considered one of the most important reasons for countries host a mega event. They generate short, medium and, long-term legacies in the destination image, as well as, at economic and sociocultural level. The paper objective is to show the short-term evolution of economic legacies indicators of sports mega-events, two years before and two years after each event. It was verified through an exploratory analysis of tourism employment level, total investment, and Tourism GDP of the countries that hosted the last three FIFA World Cups. Also, it analyzes the country's competitive strengths at the year that the megaevent happened based on the Tourism \& Travel Competitiveness Index pillars (TTCI). Thus, it performed an explanatory and descriptive analysis of secondary data. Literature review points out the infrastructure as the central pillar to receive a sports mega-event. However, the results did not indicate this focus in the last countries chosen. Also, the economic legacies had increased after the sports mega-event, but not in all hosts analyzed. Therefore, the assumption of positive effects generated by sports mega-events is not consolidated. Further research is recommended to establish indicators and approaches the impact on the host country by a mega-event from the legacy perspective.
\end{abstract}

Keywords: Sports Mega-events; Tourism Competitiveness; Economic Legacy; Tourism Impact.

\section{RESUMEN}

Los impactos del legado turístico son un importante motivo para los países acoger un mega evento. Estos eventos generan legados a corto, mediano y largo plazo en la imagen de destino, así como a nivel económico y sociocultural. El objetivo del artículo fue mostrar la evolución a corto plazo de los indicadores de legado económico de mega eventos deportivos considerando 
dos años antes y dos años después de cada evento. A través de un análisis exploratorio se verificó el nivel de empleo turístico, la inversión total y el PIB turístico de los países que acogieron las últimas tres Copas Mundiales de la FIFA. Además, se analizó las fortalezas competitivas del país en el año en que ocurrió el mega evento en base a los pilares del Índice de Competitividad Turística y de Viaje (TTCI). Este análisis explicativo y descriptivo está basado en datos secundarios. La revisión de la literatura señala la infraestructura como el pilar competitivo central para un país recibir un mega evento deportivo. Sin embargo, los resultados no indicaron este punto como una fortaleza en los últimos países elegidos. Además, el legado económico aumentó después del mega evento deportivo, pero no en todos los hosts analizados. Por lo tanto, la asunción de los efectos positivos generados por los mega eventos deportivos no se consolida y así se recomienda investigaciones futuras bajo la perspectiva del legado para establecer indicadores y análisis sobre el impacto en el país anfitrión generado por un mega evento.

Palabras clave: Mega eventos deportivos; Competitividad turística; Legado económico; Impacto del turismo.

\section{INTRODUCTION}

Sports events and mega-events have been reported as a promising segment of the tourism industry (Deery, Jago and Fredline, 2004). This modality of tourism has proliferated, motivated by the hope of significant economic impacts (Funk and Bruun, 2007; Wong, 2011; Barajas et al., 2012) and legacies (Barget and Gouguet, 2007). The study of sport event legacies has grown rapidly since 2000 across several papers and disciplines related to planning and hosting large-scale sport events, as well as the impact on society and its repercussions (Barajas et al., 2012; Thomson et al., 2018). According to Li and Balke (2009), impacts can be defined as the effects during the event holding period; On the other side, legacies consider tourist flow of host country before and after the event, as well as, the event holding period, providing an assessment of total tourism impacts.

Mega-events take place on a large scale, regarding audience, target market, level of financial involvement of the public sector, political effects, media, television coverage and construction of facilities and infrastructure. They have economic and social impacts on the host society (Hall, 2006). According to Roche (2000) "mega-events are better understood as cultural events (including commercial and sports events) of large scale, which have a dramatic character, mass popular appeal, and international significance." These events are considered moderns because they traditionally integrate industrial and corporate interests with governmental issues related to urban development and the national image (Schimmel, 2006).

Events of these magnitude offer opportunities to gain the world's attention, and to shape or reshape the international image of a city or country, especially the sports events (Caiazza and Audretsch, 2015). Governments have two main reasons to encourage the international sports events. They generate a double positive effect on the country: business and medals. Indeed, every type of mega-events creates advertising and marketing to the host country (Getz, 2008; Horne, 2006; 2007), however, usually socio-economic legacies are the main reason to host a mega-event (Cornelissen, 2004). Regarding sports events, legacy is "all planned and unplanned, positive and negative, intangible and tangible structures created for 
and by a sports event that remains for a longer time than the event itself" (Preuss, 2007, p.86). These legacies usually are divided into three dimensions: economic, physical and psychological well-being, and its effects can be a short, medium or long-term (Li and McCabe, 2013).

Theoretical assumptions indicate a positive relation between mega-events and economic performance, as well as with tourism competitiveness (Ritchie \& Crouch, 1997; Dwyer, Forsyth and Spurr, 2006; Mair and Whitford, 2013; Pinson, 2016). Nevertheless, other theoretical views, question these statements, primarily related to sports mega-events (Horne, 2006; 2007; Giampiccoli, Lee and Nauright, 2015). Thus, this work contributes to a general view based on legacy perspective.

We analyzed the variations of economic indicators of the tourism industry in host countries of a sport mega-event. To determine whether there are positive changes in tourism impacts (ex-ante) and, short-term economic legacy (ex-post) was verified the period immediately before, during, and after of the last three editions of FIFA world cup.

This study followed the proposition of economic legacy indicators according to Li and McCabe (2013) approach. Tourism GDP variation, tourism direct jobs variation and changes in the level of tourism investment in the countries that hosted FIFA World Cup (Germany, South Africa, and Brazil) was analyzed. Tourism \& Travel Competitiveness Index (TTCI) of the World Economic Forum (WEF) were identified to verify tourism competitive strengths of these hosts. Additionally, the current rankings of TTCI pillars to the two host countries for the next editions of the event (Russia and Qatar) were observed to establish a parallel with the previous hosts.

\section{EVENT TOURISM AND SPORT MEGA-EVENTS}

Event tourism, conferences, congresses, and conventions are a type of travel in which the primary objective is the meeting (Getz, 2008). The conceptual framework of event tourism in a scientific perspective was first developed in a paper published in 1989 authored by Donald Getz: "Special Events: Defining the Product." In this article, the author defines event tourism as some branch of travel that contributes to the development of tourism destinations. To Getz (2008) events can be categorized by their geographical scope (local, regional, or international), or by the type of meeting (cultural, religious, sporting, commemorative, political, artistic, commercial, educational, scientific, etc.).

Olympic Games and the FIFA World Cup are 'Hallmark tourism events,' also known as sports mega-events. They have potential to create substantial enduring impacts on the growth of international travel to the host region (Hall, 2004; Giampiccoli, Lee and Nauright, 2015). Hallmark events are related to quality, tradition, and advertising, and usually, establish a link with the tourism destination, have a high power of attraction, and can contribute to the international place branding (Getz, 2008). Nevertheless, empirical evidence both favorable and in opposition to this assumption are showed by scholars of tourism (Solberg and Preuss, 2007; Giampiccoli, Lee and Nauright, 2015).

This tourism modality contributes to several economic activities, as well as, to other types of tourism. Thus, many countries or cities seek to become a meeting destination (Hanrahan and Maguire, 2016). Some motives point out by scholars are: events generate 
advertising on the tourism destination; they lead to a high number of repeat tourists; the tourists' daily spending in the destination is higher than in other tourism modalities; they improve the image, provide restoration of decaying neighborhoods, rejuvenation of central areas, and improvement of civic pride among residents and, they can be used to maintain tourist flow during low season periods, thereby helping to combat seasonality (Crouch and Ritchie, 1997; Linda, 2009; Monge and Brandimarte, 2011; Wan, 2011; Giampiccoli, Lee, and Nauright, 2015).

Emerging tourism destinations are using meeting tourism as an opportunity to develop their overall tourism and incentivize a change in the traditional tourism routes (Crouch \& Ritchie, 1997). Researchers recognize the capacity of the mega-events to improve tourism infrastructure, especially the sports events (Auld and Macarthur, 2003; Pacaud et al., 2007; Haferburg, 2011). Indeed, tourism destinations compete to attract events based on their attractiveness and infrastructure (Oppermann, 1996; Qu H. et al., 2000; Linda, 2009; Monge and Brandimarte, 2011; Wan, 2011; Wong, 2011), but different factors are strengths in the election of a mega-event host. Scholars use various perspectives, for instance, O'Neill (2001) suggests that the choice of a country to host the World Cup is partly based on the geopolitical reconfiguration between North and South, marked by the economic growth of Brazil, Russia, India, and China.

Most destination management organizations believe that hosting sports events cause positive shifts in tourism demand on a short and long-term basis, but the additional revenues might not counterbalance the investment costs required in the venue (Solberg and Holger, 2007). Preparing a city for a sports event takes several years and usually requires substantial expenditure. Mega-events need high financial inputs to build infrastructure, and a joint effort among the private and public sectors and the local community (Loftamn and Nevin, 1995). On the one hand, they improve infrastructure in the country; on the other hand, the investment in stadiums to sports mega-events will be wasted if the facilities are not efficiently used after an event mainly because the costs to maintain them are high (Li and McCabe, 2013).

Regarding impacts of events, there are different ways to analyze them. According to Getz (2008), in the 1990s the focus was only on the economic dimension. In this line are studies of Treasury (1997), Crompton and McKay (1994), Crompton (1995), Dwyer and Forsyth (1997), Delpy and Li (1998), and Mules (1999). In the 2000s, the research added social and cultural impacts of mega-events, for example, the studies of Dwyer, Mellor, Mistillis and Mules (2000) and, Delamere, Wankel and Hinch (2001). Potential economic and social impacts as legacies to communities were focused (Hiller, 2000) generating a new perspective on tourism events which were extended to sports mega-events.

Sport event legacies can be considered the planned and unplanned, positive and negative, tangible and intangible structures created for and by a sport event that remain longer than the event itself (Preuss, 2007). Sport event legacies are typically associated with sport events of a scale that require significant investment in infrastructure and urban development, have international media exposure, and attract large numbers of tourists (Thomson et al., 2018). 
The studies on impacts and legacy of mega-events usually adopt the words 'short-term' to refer to the period immediately before, during, and after the event (Solberg and Preuss, 2007). While, the long-term period is the one that begins with the bidding for the event and ends at some point in the future yet to be determined (Kang and Perdue, 1994). Also, it common the expressions 'ex-ante or ex-post approach' to define the temporal model used to study the effects of mega-events.

Preuss (2007) studied legacies of sports mega-events, considering those that remain for a longer time than the event itself. Some studies consider legacy as long-term results (Barget and Gouguet, 2007), others include short-medium-and long-term results, that is, defining different stages of legacies (Li and McCabe, 2013). In this view, tourism impacts are those that occur during the holding period and event (Li and Blake, 2009).

A study with ex-post approach targeted to estimate the level of employment in the Olympic Games' absence was performed by Baade and Matheson (2002). They found that the economy virtually returned to its 'normal' pattern afterward and the increase in economic activity attributable to this mega-event was temporary, it means, was an impact but not a legacy. Indeed, post-mega effects in new business activities or employment are questionable. Sometimes, the level of income and investment falls after the mega-event (Kasimati, 2003), configuring an interesting case of negative legacy although the country registered a positive impact.

In fact, studies on tourism impacts of mega-events mention some issues regarding legacy, although most of them do not use the legacy concept or its terminology. This situation can be understood as an imprecision or not; it depends on author's theoretical background since the impacts are one type of short-term legacy. Also, the legacy concept is relatively new in the mega-events field, while the concept of impact is much more established, therefore is commonly used (Li and McCabe, 2013).

There are different viewpoints, but the scholars agree that tourism legacy is the more significant motivation for countries to host a mega event (Cornelissen, 2004), although most legacies just become apparent in long-term (Li and McCabe, 2013). According to Li and McCabe $(2013$, p.3) legacy is "...tangible and intangible elements of large-scale events left to future generations of a host country, where these elements influence the economic, physical and psychological well-being at both community and individual levels in the long-term". Figure 1 shows the legacy framework of these authors. 
Figure 1. Legacy Framework

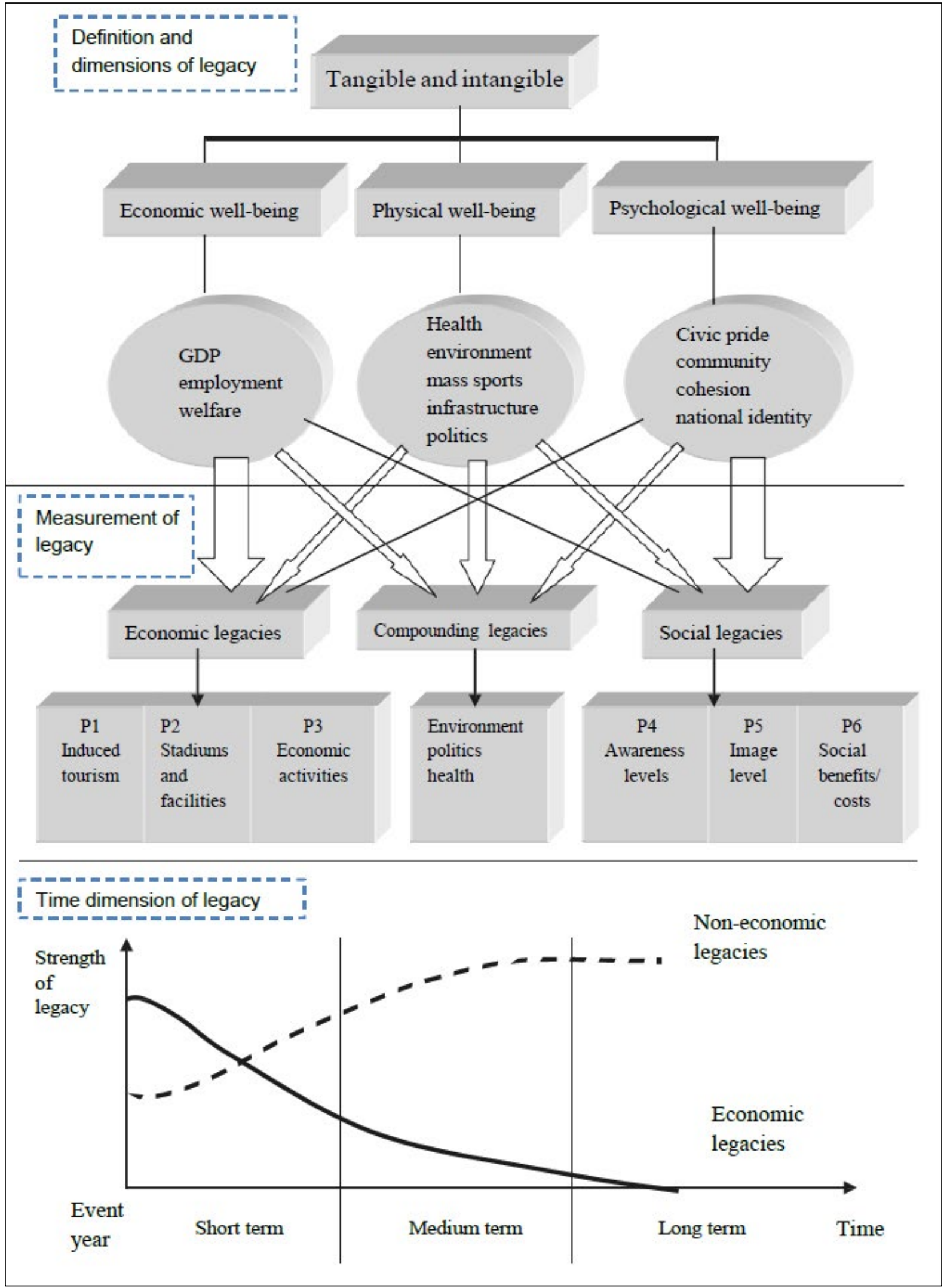

Source: Li \& McCabe (2013). 
Requests for hosting a sport mega-event have grown significantly over the last two decades, even though empirical proofs on tourism gains by mega-events are few (Kasimati, 2003). Both, the unavailability of data on tourism effects in the host country and the difficulty in separating the normal evolution of tourism from that derivate by mega-events, hinders to prove the tourism legacy cause by a mega-event. In the last decade, scholars have paid more attention to the potential gains concerning economic returns (Fourie and Santana-Gallego, 2011), probably because it is easier to verify that social and compounding legacy.

The framework for measuring the legacies of mega-events proposed by Li and McCabe (2013) has dimensions of tangible and intangible legacy, which are divided into economic, physical and phycological well-being (Figure 1). These dimensions generate three categories of legacy, Economic, Compounding, and Social. Economic legacy can be verified by economic well-being, including GDP, employment rates, and well-fare to represent economic legacies. These variables are inductors of tourism and contribute to developing infrastructure, as well as, impact on the business activities. Environments, policies, and health can express the results on Compounding legacies; while social benefits/costs, image and awareness level represent the Social legacy. However, there a timeline of effects. In a short-term, economic legacy are higher than other types of legacies, but this evolution line is inverse. Thus, in a medium-largeterm, compounding and social legacies increase and economic legacy decrease. Nevertheless, $\mathrm{Li}$ and McCabe (2013) highlighted the interrelations among them. Thus, economic legacy is better observed in a short-term, but its effects follow in the time through the influence in the other legacies categories.

\section{METHODOLOGY}

The research used a qualitative methodology based on secondary data from official sources. It is an exploratory, descriptive study to identify the competitiveness indicators of hosts FIFA World Cup and economic effects, that is, economic legacy. For this, a longitudinal analysis is performed to verify progress or decline of economic indicators considering the pre-post-event period. Although this study focuses on ex-ante and ex-post tourism impacts, it considers two years (ante and post). Thus, it is an analysis of short-term legacies. This timeline followed Li and McCabe (2013) perspective which considers economic effects are higher in this period.

The analysis was carried out through the following stages:

1. Content analysis of TTCI to identify and compare the indicators ranking of each country, in the year that hosted the World Cup event, to reveal the efforts of each nation;

2. To analysis a longitudinal series of economic variables whose variation can be related to the results pre-post mega-events (two years before and two years after), including contribution of tourism to national GDP, investment in the tourism sector, and the number of direct jobs in the tourism sector;

3. Comparison of variables discrepancy in the period analyzed for each country that hosted the World Cup mega-event; 
4. Analysis of next host countries regarding competitiveness pillars and the economic variables previously presented;

5. Final considerations on the results considering the theoretical backgrounds.

\subsection{Context of analysis}

FIFA define the host region to World Cup according to alternation among the Asian Confederation Football, African Confederation Football, Confederation of North, Central American and Caribbean Association Football, Union of European Football Associations, Oceania Football Confederation and South American Confederation Football. As regards a country to host the event, must have at least 12 football fields with a minimum capacity of 40,000 people; a stadium for the final game with 80,000 seats, at least (the rule is valid for 2018 until then, the requirement was 60,000 seats).

It is also examined the capacity to broadcast the event to TVs around the world, technology to support the large volume of information exchange (the internet and phone), transport infrastructure and accommodation. On the other side, general conditions of the candidate are verified, that is, several items that reflect competitiveness pillars of the country are analyzed. Currently, FIFA announced that respect for human rights would be a decisive factor in the next disputes (FIFA, 2017).

The Global Competitiveness Report is developed and published by the World Economic Forum (WEF) since 2007 offering a series of reports on integration and world economy. For instance, the Financial Development Report, the Global Commercial Report, the Global Information, and Technology Report and, the Tourism \& Travel Competitiveness Index (TTCI). The institution also performs numerous regional and country studies, therefore, constitute an available source of information.

The range of $\mathrm{TTCl}$ scale is value 1 to 7 . The less tourism competitive level is 1 , and the most is 7. Currently, 141 countries are being monitored through 14 pillars grouped in four subindexes that is measured by 90 variables, generating an aggregate index through an unweighted average (Figure 2). Enabling Environment subindex captures general settings necessary for operating in a country, while, T\&T Policy and Enabling Conditions subindex verify specific policies or strategic aspects that impact the T\&T industry directly. At the turn, Infrastructure subindex captures the availability and quality of physical infrastructure of each economy; and Natural and Cultural Resources subindex expresses the principal reasons for traveling to the country (Figure 2). 
Figure 2. Pillars of Travel \& Tourism Competitiveness Index - TTCI

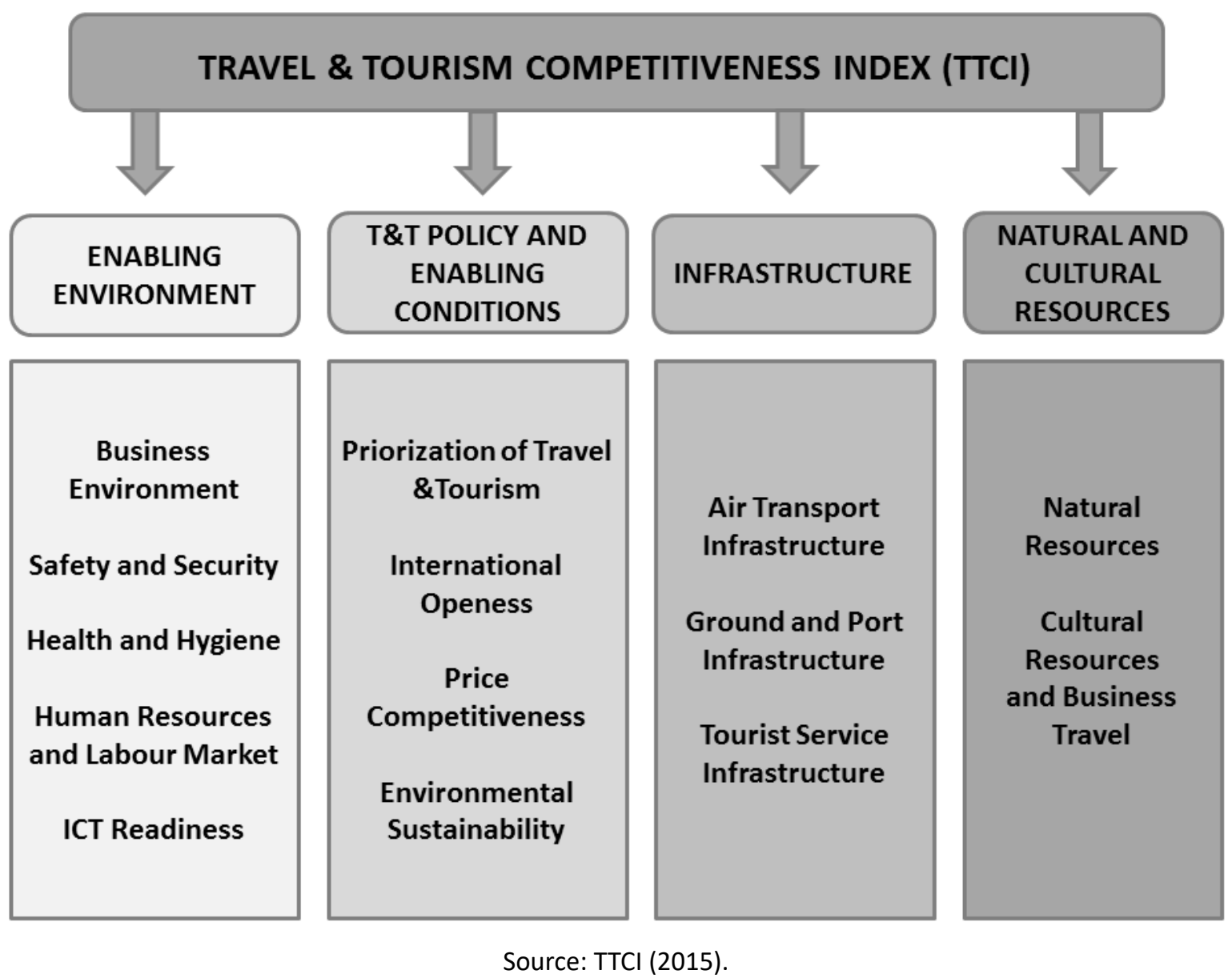

$\mathrm{TTCl}$ measures the factors that make the country attractive to investors or for the development of business in the travel and tourism sector. However, it should not be mistaken with the measurement of the attractiveness of the country as a tourism destination (WEF, 2007). The determinants of competitiveness elements are numerous and complexes highly. According to the WEF, competitiveness is the set of institutions, policies, and factors that determine the productivity of a country (WEF, 2015). During the period from 2006 to 2015, there were three World Cups: Germany in 2006, South Africa in 2010, and Brazil in 2014. These countries have a different level of economic and tourism development. Germany is in 3rd position in the TTCI ranking, Brazil occupies the 28th place, and South Africa are in the 48th position (WEF, 2015).

\section{TTCI PILLARS IN THE HOST COUNTRIES OF FIFA WORLD CUP}

Table 1 shows the ranking of tourism competitiveness pillars at the year which the country hosted the World Cup mega-event. Besides, it presents the pillars ranking of countries where will be next editions of this mega-event: Russia for 2018 and Qatar for 2022. In this case, the values were based on the year that FIFA chose them, that is, the year of 2015. 
Table 1. Competitiveness pillars of TTCI (Tourism \& Travel Competitiveness Index) of World Cup country host

\begin{tabular}{|c|c|c|c|c|c|}
\hline $\begin{array}{c}\text { TTCI Pillars } \\
\text { (Based on } 2015 \text { structure) }\end{array}$ & $\begin{array}{c}\text { Germany } \\
\text { TTCI } \\
2006-2007\end{array}$ & $\begin{array}{c}\text { South Africa } \\
\text { TTCI } \\
2010-2011\end{array}$ & $\begin{array}{c}\text { Brazil } \\
\text { TTCI } \\
2014-2015\end{array}$ & $\begin{array}{c}\text { Russia } \\
\text { TTCI } \\
2015\end{array}$ & $\begin{array}{l}\text { Qatar } \\
\text { TTCI } \\
2015\end{array}$ \\
\hline Business Environment & 5.67 & 4.85 & 3.60 & 3.98 & 6.05 \\
\hline Safety and Security & 6.26 & 3.52 & 4.68 & 3.95 & 6.61 \\
\hline Health and Hygiene & 6.23 & 4.10 & 5.31 & 6.69 & 5.97 \\
\hline Human Resources and Labour Market & 5.52 & 3.73 & 4.51 & 4.83 & 5.23 \\
\hline ICT Readliness & 5.31 & 2.59 & 4.43 & 4.83 & 5.44 \\
\hline Priorization of Travel and Tourism & 3.90 & 4.53 & 4.05 & 4.33 & 4.89 \\
\hline International Openess & 4.54 & 4.87 & 2.59 & 2.48 & 1.93 \\
\hline Price Competitiveness & 3.56 & 4.94 & 4.51 & 4.99 & 5.33 \\
\hline Environmental Sustainability & 6.05 & 4.86 & 3.89 & 3.70 & 4.32 \\
\hline Air Transport Infrastructure & 5.39 & 3.89 & 3.64 & 4.42 & 4.17 \\
\hline $\begin{array}{l}\text { Ground and Port Transport Infrastruc- } \\
\text { ture }\end{array}$ & 6.58 & 3.73 & 2.36 & 3.09 & 4.79 \\
\hline Tourism Service Infrastructure & 5.28 & 4.27 & 4.69 & 4.65 & 4.81 \\
\hline Natural Resources & 6.75 & 4.76 & 6.01 & 3.77 & 2.12 \\
\hline Cultural Resources and Business Travel & 6.75 & 2.89 & 5.31 & 3.32 & 1.48 \\
\hline
\end{tabular}

Source: Elaborated by the authors based on TTCI.

Germany received the World Cup in 2006. Its rankings of tourism competitiveness pillars indicated a nation with high transport structure, i.e., excellent accessibility. Other strengths were safety, hygiene, health, and sustainability, as well as a high degree of natural and cultural resources. All the pillars were above $85 \%$ in the competitiveness scale, except price competitiveness and prioritization of the sector. Thus, the data indicate that this tourism destination already had an adequate infrastructure to receive mega-events, and enabled a complementary tourism offer to the event. Regarding the low level in the ranking of the prioritization of the industry, the fact of hosting a mega-event tends to help improve this indicator, since it generates mobilization within the country, both public and private, around the tourism industry.

South Africa presented a very different situation when compared to Germany since few pillars were beyond the middle level. None of them exceeded $70 \%$ of the $\mathrm{TTCl}$ scale, that is, all the components were below 5 points. Best tourism competitiveness pillars were international openness, price competitiveness, sustainability, natural resources and the business environment. In the medium level (around 3.5 points) were accessibility, security and health and hygiene. This context indicates that the decision to host a World Cup in South Africa was based on other variables, such as price levels, and the contribution to tourism development in countries that are in the process of consolidating themselves as a tourism destination more than infrastructure. 
In 2014, the pillars of tourism competitiveness of the host country (Brazil) also did not indicate an association with excellent infrastructure. The three best TTCI pillars in the country, although none of them exceeded $75 \%$ on the scale, were: natural and cultural resources and, health and hygiene. The safety and security, as well as, the structure of tourism services presented levels of $70 \%$ on the scale. The worst level in the country was internal accessibility in the destination, environmental sustainability, and international openness. However, TTCI pillars indicated that the state offers good leisure tourism, being a corresponding point to a mega-event, which may have influenced positively in the process of choosing Brazil as a World Cup venue, despite the low accessibility index and other negative indicators.

Regarding future editions of the World Cup, although the TTCI rankings could change, it is already decided that the 2018 edition will be in a country that prioritizes the tourism sector, health and safety and, has good price competitiveness (Russia). The nation has a medium competitiveness about resources that generate additional travel offer to the event, for example, natural and cultural resources. On the other hand, the 2022 edition will be in a country (Qatar) whose strength is in safety, health and hygiene, business environment and human resources for tourism. It has good tourism and accessibility structure but less competitiveness of natural and cultural resources. These two last pillars are dimensions whose variations are quite hard to generate through investments; therefore, it indicates that this edition of the World Cup may have a lower supply of additional tourism.

\section{ECONOMIC VARIABLES IN THE HOST COUNTRIES OF FIFA WORLD CUP}

The importance of mega-events to propel tourism development in the country is emphasized (Kim et al., 2006). However, tourism GDP does not depend exclusively on this tourism modality or strategy. GDP is affected by market variations, economic crises, and so on. Even so, it is essential to observe the change of this indicator in countries that hosted mega-events. The same condition occurs with the level of jobs in tourism and the level of investments made in the sector, which is influenced by various changes in the market. Although its variation is also related to the mega-event, the weight of this influence may be low when compared to other market forces which interact in its performance.

Germany's tourism GDP in 2006 was the highest in the period analyzed. Nevertheless, the country failed to maintain this performance. In the two years that followed the event, Germany accumulated a negative variation of $5.48 \%$ (Figure 3 ). Curiously, tourism GDP in the year that South Africa hosted the World Cup did not have its best performance in this series. However, in the followed five years the sector GDP recovered the accumulated losses of the pre-event period and continued to grow, reaching an increase of 8,34\% in South Africa. In Brazil, tourism GDP presented a peak in the year in which it hosted this mega-event. Nevertheless, country results followed a similar Germany trend, that is, it failed to maintain tourism GDP growth (Figure 3). 
Figure 3. Tourism GPD of 2006 to 2015 and its World Cup variation

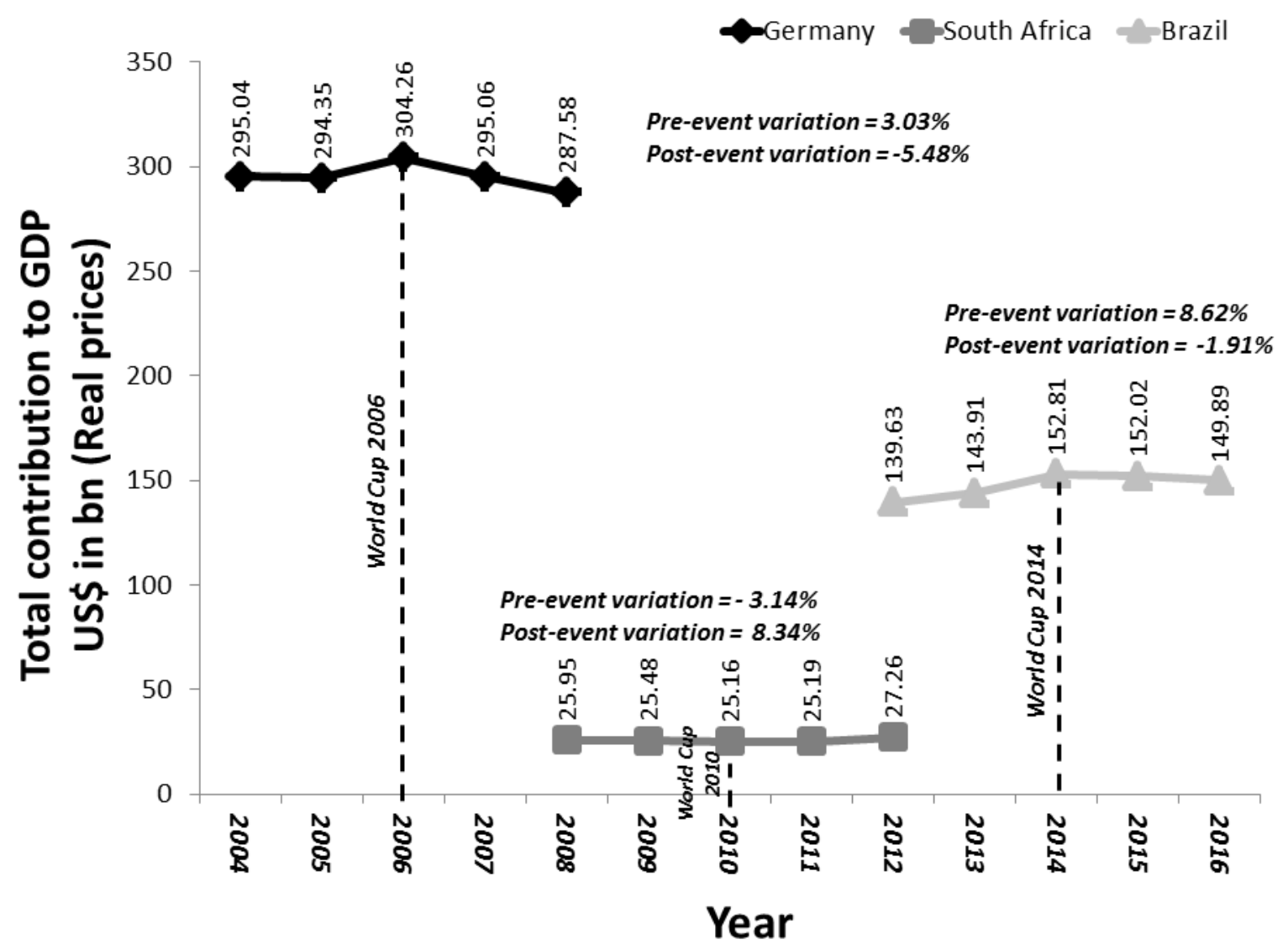

Source: Elaborated by the authors based on WTTC.

The number of direct jobs in tourism reached the highest level in the year in which Germany hosted the mega-event, but it falls in the two subsequent years. The post-event accumulated result was negative (-7.90\%) in the level of tourism jobs (Figure 4). In South Africa, there was a similar situation to the tourism GDP. The year that hosted the event did not present its better result in tourism jobs. Nonetheless, in the subsequent years, the tourism jobs gradually increased improving $14.78 \%$. In Brazil, the jobs in tourism had presented a continuous growth both pre and post-event. Although in the post-event period the rate was lower, which produced a reduction from $8.61 \%$ to $4.93 \%$ in the job growth in the sector. 
Figure 4. Tourism Jobs of 2006 to 2015 and its World Cup variation

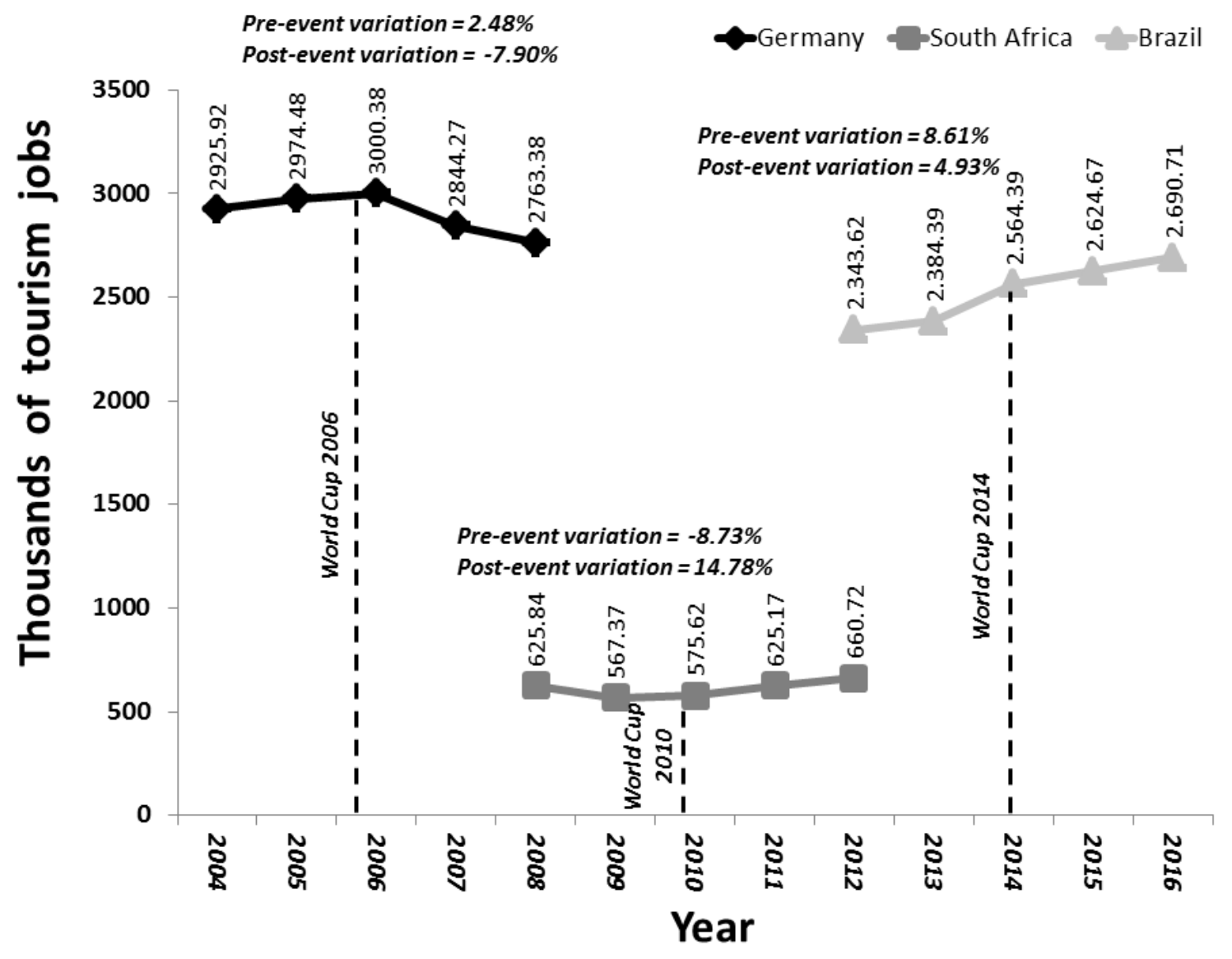

Source: Elaborated by the authors based on WTTC.

Finally, investments in the tourism sector should be observed, since it is entirely recognized by researchers that mega-events generate infrastructure in the countries. Investments are an economic legacy that produces compounding legacy, as infrastructure which requires high levels of public and private investments both in building and maintenance. Although Germany presented good infrastructure, the country performed a high investment in the year of the World Cup event; the pre-event variation was $20.57 \%$ regarding tourism investment. Besides, in the post-event period, the country continued to invest in the sector reaching more $18.48 \%$ to investment level (Figure 5).

In South Africa, TTCI pillars showed low infrastructure. Thus, the two years before the event presented a high investment in the sector. That was indicated a country's preparation for host the mega-event and to develop the tourism sector. However, tourism investment was lower in the year of World Cup producing a negative variation (-38.97\%). After this megaevent, the tourism investment started to grow again, though it was significantly less $(6.8 \%)$. In Brazil, infrastructure also did was not the most reliable pillar of competitiveness, so the levels of investment in previous years to World Cup showed a progressive growth achieving $14.83 \%$. However, in the last two years, tourism investment was falling, resulting in $-3.76 \%$ losses. This 
evolution indicated that the country's preparation occurred gradually, but the sector was not able to maintain the investment pace (Figure 5).

Figure 5. Investment in the tourism sector between 2006-2015 and post-World Cup Variation

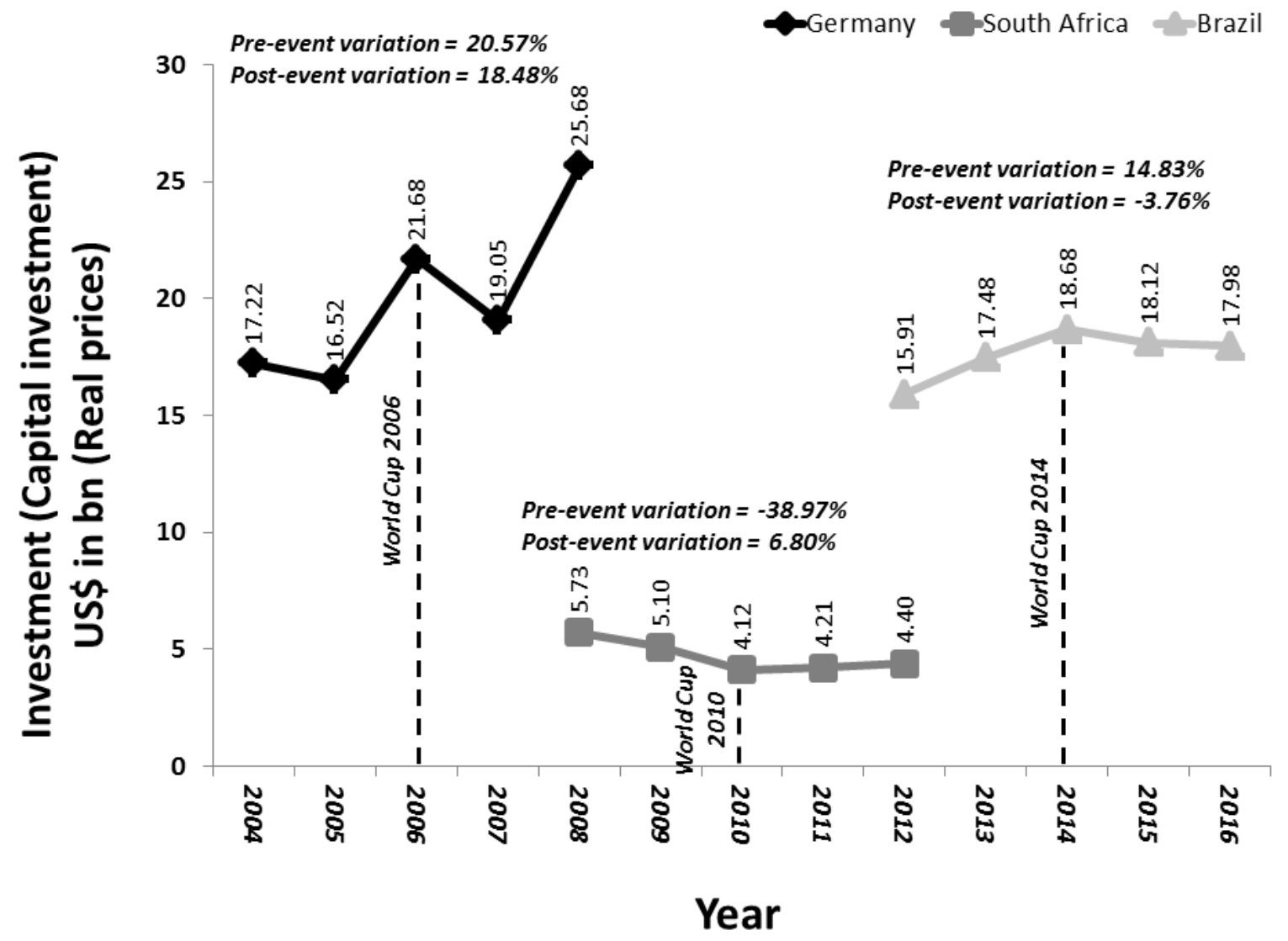

Source: Elaborated by the authors based on WTTC.

Figure 6 shows the percentage variation in the indicators, considering the post-event period of the World Cup in each country. Thus evolution 2006 to 2008 in Germany, 2010 to 2012 in South Africa and, 2014 to 2016 in Brazil. Note that Germany, despite the high growth in levels of tourism investment, presents negative growth in tourism GDP and the number of direct tourism jobs that means negative economic legacies. On the other hand, South Africa shows positive changes in three indicators. At last, in Brazil, the tourism job level continues to grow, despite the losses in the tourism investment and GDP. Indeed, many other factors are influencing these results, such as economic crises and the fact that they are emerging destinations. It is interesting to note that the country with the best infrastructure to host a mega-event maintains the highest investments in the sector. However, it accumulated losses in tourism jobs, as well as in tourism revenue. In a general overview, considering this short period and the comparison between the last three host world cup countries, South Africa seems to have achieved better results regarding economic legacy (Figure 6). 
Figure 6. Variation of tourism investment, tourism jobs and the sector's contribution to GDP after the World Cup

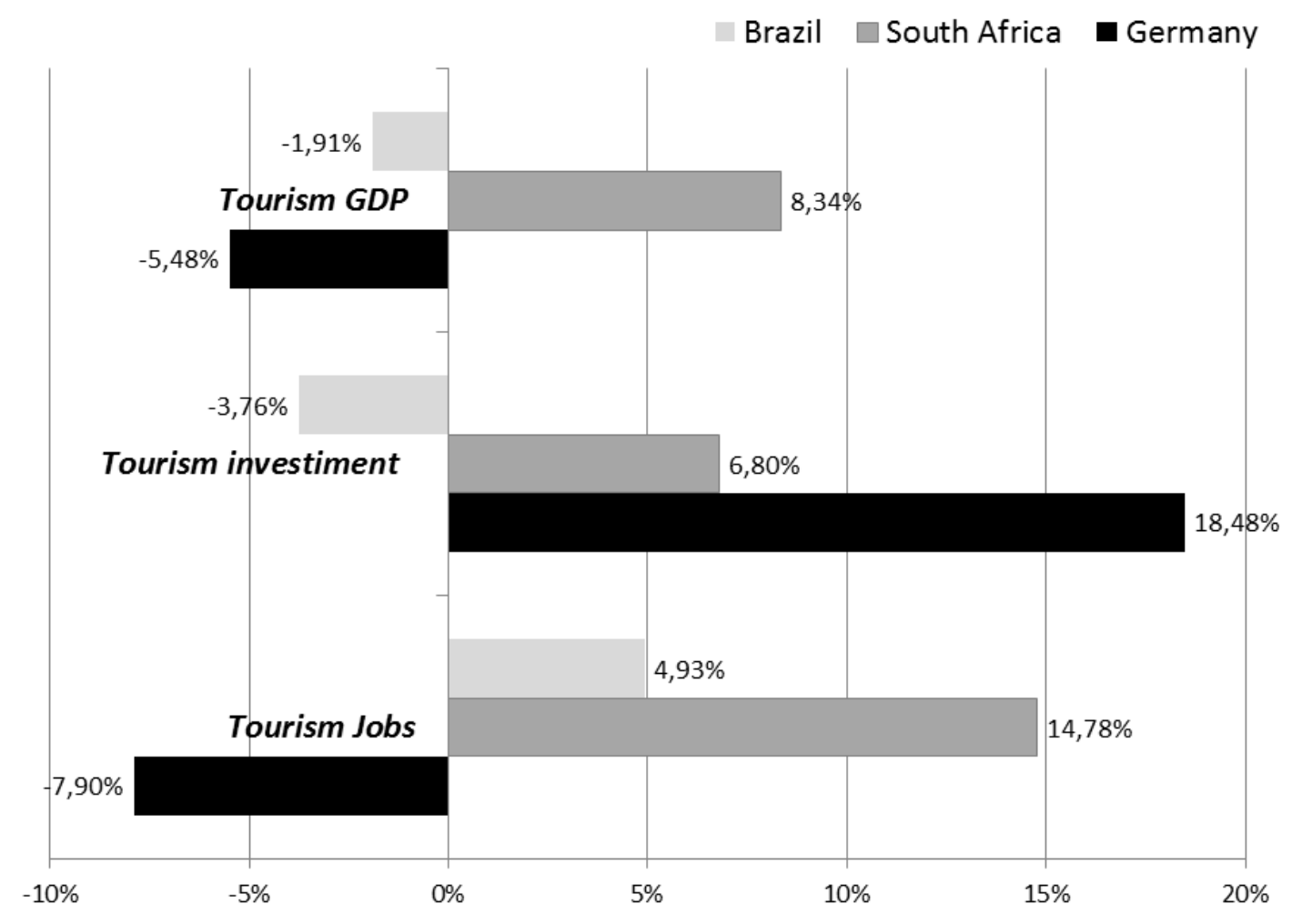

Source: Elaborated by the authors based on WTTC.

Russia and Qatar will host the World Cup in the next two editions. In both cases, the tourism sector does not have an economic presence in the national GDP, especially in Qatar. Nevertheless, tourism can be considered an emergent industry to the countries that will be the venue of this mega-event for its next two editions, since they show growth in the number of tourism jobs. It is an indication that although tourism has low participation in the GDP, they are organizing themselves and tend to grow in this sector (Table 2). Regarding tourism investment level, Russia and Qatar indicate very low scores; although, their competitiveness in tourism infrastructure is above the average of TTCI scale (see Table 1). To emergent destinations host a mega-event such as World Cup is a strategic action which can produce some results. 
Table 2. Overview of tourism economic variables of future host countries to World Cup

\begin{tabular}{|c|c|c|c|c|c|c|c|}
\hline \multicolumn{2}{|c|}{ Economic variable } & $\mathbf{2 0 1 2}$ & $\mathbf{2 0 1 3}$ & $\mathbf{2 0 1 4}$ & $\mathbf{2 0 1 5}$ & $\mathbf{2 0 1 6}$ & Variation \\
\hline \multirow{4}{*}{ Russia } & Tourism Jobs (Thousands of jobs) & 896.03 & 912.06 & 974.44 & 973.50 & 1002.11 & $10.59 \%$ \\
& Tourism investment - US\$ in bn (Real prices) & 7.25 & 7.28 & 7.18 & 6.43 & 6.26 & $-15.84 \%$ \\
& Tourism GDP - US\$ in bn (Real prices) & 66.55 & 67.36 & 72.04 & 69.72 & 69.98 & $4.90 \%$ \\
\cline { 1 - 5 } Qatar & Tourism Jobs (Thousands of jobs) & 61.79 & 66.28 & 73.03 & 79.28 & 79.56 & $22.34 \%$ \\
& Tourism investment - US\$ in bn (Real prices) & 1.13 & 1.19 & 1.47 & 1.78 & 2.09 & $45.68 \%$ \\
& Tourism GDP - US\$ in bn (Real prices) & 7.88 & 8.79 & 10.78 & 13.33 & 14.12 & $44.17 \%$ \\
\hline
\end{tabular}

Source: Elaborated by the authors based on WTTC.

Economic indicators confirm this trend. In the last five years, Qatar has performed a significant investment in the tourism sector $(+45.68 \%)$, as well as; it presents a high growth in the tourism GDP (+44.17\%). These rates act on the level of tourism job which also improved in the period $(+22.34 \%)$. On the contrary, the variation on tourism investment among 2012 to 2016 in Russia was negative (-15.84\%), but the tourism job and GDP had grown, $10.59 \%$ and $4.9 \%$, respectively (Table 2 ).

\section{CONCLUSIONS}

The decision to host a mega-event as World Cup depends on several factors. Although the scholars on events indicate that infrastructure and accessibility are critical variables for the choice of venue (Qu et al., 2000; Wan, 2011), some researchers consider essential the complimentary offer of leisure tourism (Kim, Yoon and Kim, 2011) as a pivotal point to choose a host country.

In fact, the selection of hosts is by a blind vote. Thus, assumptions can be made after the fact, but there is no way to determine how these factors are weighted by voters. Though based on the results of this exploratory analysis, the last choices of host for the FIFA World Cup did not indicate a focus on infrastructure, because it was observed hosts with the high competitiveness of natural and cultural resources, like Brazil and South Africa, but low infrastructure. This focus, though, is not seen for the host countries of future editions, since the strengths of Russia and Qatar are safety, health, and hygiene according to TTCI pillars. This choice may be induced by the series of terrorist incidents and epidemics that have occurred in the global context.

Also, the literature review indicated the price level as a decisive factor for the choice of hosts for events (Wong, 2011; Tanford, Montgomery and Nelson, 2012). Regarding this indicator, Germany was not a competitive country, but the following countries (South Africa and Brazil) had better ranking in this pillar. The next two hosts of the World Cup also are competitive on price pillar. Due to the economic crisis which affects tourism consumption level, a focus on this item to choose a host was expected.

In conclusion, the infrastructure remains as an important factor, and for certain types of events, it is essential. But for the choice of the World Cup host country, other factors are also considered, such as a complimentary offer of leisure tourism and security since infrastructure 
can be built for the mega-event during the selection/application period and even during the year of the event.

The variables that are directly impacted by mega-events, such as levels of employment in the sector and tourism GDP showed improvements in the year of the event, as were expected for the World Cup host countries. However, the variation was not very important. To emergent destinations, as well as, developing countries, like South Africa and Brazil the economic legacy was positive. On the other hand, the developed country, Germany had a negative legacy although this analysis is not conclusive, due to it considered merely one among many factors that influence the performance of these indicators.

Our objective did not focus on the two other categories of legacy defined by Li and MacCabe (2013), compounding and social legacy. However, to Blake (2000), evolution in Economic welfare can be equivalent to changes in real GDP (Blake, 2000). Nevertheless, tourism economic legacy based on the theoretical perspective of Li and McCabe (2012) occurred only South Africa presented better economic welfare in the post-event period because the other two countries the tourism GDP decreased. Thus, a probably low legacy from World Cup megaevent regarding welfare also is expected in Germany and Brazil.

The study of Siegfried and Zimbalist (2000, p. 103) found no significant statistical correlation between the construction of sports facilities and positive long-term economic development. While Li \& McCabe (2013) supposed that event stadiums and others, related facilities can bring tangible and direct legacies after an event finish. In the same line, Barclay (2009) notes that investments in infrastructure for mega-events can have long-term benefits. However, this research could not provide information to verify this dimension of legacy. They represent compounding and social legacies, therefore were not object of analysis in this research.

Indeed, the political and strategic management carried out by a country related to events, or mega-events are long-term, as well as its possible outcomes. Many improvements in variables such the country's image, both for tourism and as a place to invest and, the general infrastructure of the country is difficult to assess but are highlighted in the tourism literature as positive factors directly related to mega-events (Crouch and Louviere, 2004), that is, legacies in short-medium-long-term.

Employment is an economic legacy driven by a mega-event according to Li and McCabe (2013), that was notorious in South Africa. The country had $14.78 \%$ more tourism employment two years after the event. Brazil also presented a legacy in employment rates, but smaller than South Africa. Meanwhile, in Germany, this economic legacy did not occur. Considering the short-term ( -2 to +2 years) around the mega-event, except in Germany, the effects were not temporary, that is, on contrary the Baade and Matheson (2002) ex-post approach whose assumption considers that the economy returns to its usual pattern after the mega-event. The employment level pattern did not return in Brazil and South Africa.

The rate of repeat visits to a country by participants of events has been identified as a contributing factor for the development and promotion of the destination (Crouch and Ritchie, 1997). Thus, despite the high investments required by mega-events, the policies to remain in the ranking of countries that receive events are an essential part of a plan for tourism 
development. However, one must keep in mind that prioritizing actions related to meeting tourism is not enough. Tourism development depends on improving the overall competitiveness of the country and its tourism competitiveness, which is composed of 90 indicators that form the tourism competitiveness pillars according to TTCI. All these variables must receive attention, through public policies and the private sector, to improve the country's overall ranking, and this context can impact on the improvement of tourist flow, levels of employment, and GDP.

Some implications can be expressed concerning our results. First of all, although tourism scholars on tourism indicate the existence of positive impacts derived from events (Ritchie and Crouch, 1997; Mair and Whitford, 2013), this exploratory research suggested that the theme is not consolidated. Several factors interact on the economic variables of a country and its tourism sector and, there is a lack of statistical data in some countries led to a gap in empirical studies on the economic impacts of mega-events. The no exclusive dependence of variables on effects of mega-events also was our main limitation in this research. Another limitation of this research was to be an exploratory study.

Additionally, this research indicates although there are FIFA criteria based on infrastructure to choose the host country World Cup, the competitiveness pillars also acts on the final election. Probably, the focus change according to the economic, political and social world context. Previously the competitive infrastructure prevailed (Germany), but it was replaced by a focus on natural resources, tourism offers and competitive prices due to a worldwide economic crisis (South Africa and Brazil). Next two editions the focus is on safety, health, and hygiene. Finally, future editions maybe the focus will be on respect for human rights, which was pointed out as new criteria. In resume, the candidate for hosting a mega-event should be competitive in the pillars more important to the worldwide social and economic context of the moment.

In face these conclusions, further research is indicated to establish indicators and approaches that can be used to measure the direct economic impact on the host country by a mega-event, as well as, apply the three dimensions of Tourism Legacy Model of Li and McCabe (2013). Also, as further research, it would be interesting to redo the analysis by introducing some control countries (for example the other candidates to host the event in each round) and a causal analysis that considers the comparative context in the region.

Another topic that should also be widely researched is the impact of mega-events on tourism competitiveness, and not only on the tourism flow, since the primary motivation of tourism destination is a collective improvement of all its organizations/institutions. The host country motivation is to strengthen the tourism sector, capture tourism impacts and legacies effects and consequently, contribute to increasing tourism flow and levels of employment. Although there is still a long way to prove that sports mega-events are a driver for the tourism development. 


\section{REFERENCES}

Auld, T., and Mcarthur, S. (2003). "Does event-driven tourism provide economic benefits? A case study from the Manawatu region of New Zealand". Tourism Economics, 9(2), 191-201.

Baade, R. A., and Matheson, V. (2002). "Bidding for the Olympics: Fool's gold". Transatlantic sport: The comparative economics of North American and European sports, pp. 127.

Barajas, Á., Salgado, J., \& Sánchez, P. (2012). Problemática de los estudios de impacto económico de eventos deportivos. Estudios de Economía Aplicada, 30(2), 441-461.

Barclay, J. (2009). "Predicting the costs and benefits of mega-sporting events: Misjudgment of Olympic proportions?". Institute of Economic Affairs, 29(2), 62-66.

Caiazza, R., and Audretsch, D. (2015). "Can a sport mega-event support hosting city's economic, socio-cultural and political development?". Tourism Management Perspectives, 14, 1-2.

Cohen, E. (1972). "Toward a Sociology of International Tourism". Social Research, 39(1), 164.

Cornelissen, S. (2004). "It's Africa's turn! The narratives and legitimations surrounding the Moroccan and South African bids for the 2006 and 2010 FIFA finals". Third World Quarterly, 25(7), 1293-1309.

Crompton, J. L., and McKay, S. L. (1994). "Measuring the Economic Impact of Festivals and Events: some myths, misapplications and ethical dilemmas". Festival Management and Event Tourism, 2(1), 33-43.

Crompton, J. L. (1995). "Economic Impact of Sports Facilities and Events: eleven sources of misapplication". Journal of Sport Management, 9, 14-35.

Crouch, G. I., and Ritchie, J. R. (1997). "Convention site selection research: A review, conceptual model, and propositional framework". Journal of Convention \& Exhibition Management, 1(1), 49-69.

Crouch, G. I., and Louviere, J. J. (2004). "The determinants of convention site selection: A logistic choice model from experimental data". Journal of Travel Research, 43(2), 118-130.

Deery, M., Jago, L., and Fredline, L. (2004). Sport tourism or event tourism: are they one and the same? Journal of Sport \& Tourism, 9(3), 235-245.

Delamere, T. A., Wankel, L. M., and Hinch, T. D. (2001). "Development of a scale to measure resident attitudes toward the social impacts of community festivals, Part I: Item generation and purification of the measure". Event Management, 7(1), 11-24.

Delpy, L., and Ming, Li. (1998). "The Art and Science of Conducting Economic Impact Studies". Journal of Vacation Marketing, 4(3), 230-254.

Dwyer, L., and Forsyth, P. (1997). "Impacts and Benefits of MICE Tourism: a framework for analysis". Tourism Economics, 3(1), 21-38.

Dwyer, L., and Kim, C. (2003). "Destination competitiveness: determinants and indicators". Current issues in tourism, 6(5), 369-414.

Dwyer, L., Mellor, R., Mistilis, N., and Mules, T. (2000). A framework for assessing "tangible" and "intangible" impacts of events and conventions. Event management, 6(3), 175-189.

Dwyer, L., Forsyth, P., and Spurr, R. (2006). "Assessing the economic impacts of events: A computable general equilibrium approach". Journal of Travel Research, 45, 59-66.

Fourie, J., and Santana-Gallego, M. (2011). "The impact of mega-sport events on tourist arrivals". Tourism Management, 32(6), 1364-1370. 
Funk, D. C., and Bruun, T. J. (2007). "The role of socio-psychological and culture-education motives in marketing international sport tourism: A cross-cultural perspective". Tourism management, 28(3), 806-819.

Getz, D. (1987). "Events Tourism: Evaluating the Impacts", in: J.R.B. Ritchie and C.R. Goeldner (eds) Travel, Tourism and Hospitality Research- a Handbook for Managers and Researchers, John Wiley and Sons, New York, pp. 27-38.

Getz, D. (1989). "Special events: Defining the product". Tourism Management, 10(2), 125-137.

Getz, D. (2008). "Event tourism: Definition, evolution, and research". Tourism management, 29(3), 403-428.

Giampiccoli, A., Lee, S. S., and Nauright, J. (2015). "Destination South Africa: comparing global sports mega-events and recurring localised sports events in South Africa for tourism and economic development". Current Issues in Tourism, 18(3), 229-248.

Haferburg, C. (2011). "South Africa under FIFA's reign: The World Cup's contribution to urban development". Development Southern Africa, 28(3), 333-348.

Hall, C. M. (2004). "The definition and analysis of hallmark tourist events". GeoJournal, 19(3), 263-268.

Hall, C. M. (2006). “Urban entrepreneurship, corporate interests and sports mega-events: the thin policies of competitiveness within the hard outcomes of neoliberalism", in: Horne, J; Manzenreiter, W. (Ed.). Sports Mega-Events: social scientific analyses of a global phenomenon. (Special Issue: The Sociological Review Monograph Series), 54(s2), pp. 59-70.

Hanrahan, J., and Maguire, K. (2016). "Local authority planning provision for event management in Ireland: A socio-cultural perspective". Journal of Convention \& Event Tourism, $17(2), 129-158$.

Horne, J. (2007). "The four 'Knowns' of sports mega-events". Leisure Studies, 26(1), 81-96.

Horne, J., and Manzenreiter, W. (2006). "An introduction to the sociology of sports megaevents", in: Horne, J; Manzenreiter, W. (Ed.). Sports Mega-Events: Social Scientific Analyses of a Global Phenomenon. (Special Issue: The Sociological Review Monograph Series), 54(s2), pp. 1-24.

Kang, Y. S., and Perdue, R. (1994). "Long-term impact of a mega-event on international tourism to the host country: a conceptual model and the case of the 1988 Seoul Olympics". Journal of International Consumer Marketing, 6(3-4), 205-225.

Kasimati, E. (2003). "Economic aspects and the Summer Olympics: a review of related research". International journal of tourism research, 5(6), 433-444.

Kim, H., Gursoy, D., and Lee, S. (2006). "The impact of the 2002 World Cup on south Korea: comparisons of pre- and post-games". Tourism Management, 27, 86-96.

Kim, S. S., Yoon, S., and Kim, Y. (2011). "Competitive positioning among international convention cities in the East Asian region". In Journal of Convention \& Event Tourism, 12(2), 86-105. Taylor \& Francis Group.

Li, S., and McCabe, S. (2013). "Measuring the Socio-Economic Legacies of Mega-events: Concepts, Propositions and Indicators". International Journal of Tourism Research, 15(4), 388-402.

Linda, S. L. L. (2009). "A competitiveness analysis of the convention tourism of China's Macao Special Administrative Region'". World Academy of Science, Engineering and Technology, 60, 600-605. 
Mair, J., and Whitford, M. (2013). "An exploration of events research: Event topics, themes and emerging trends". International Journal of Event and Festival Management, 4(1), 6-30.

Monge, F., and Brandimarte, P. (2011). "Mice tourism in piedmont: economic perspective and quantitative analysis of customer satisfaction". Tourismos: an international multidisciplinary journal of tourism, 6(1), 213-220.

Mules, T. (1999). "Estimating the Economic Impact of an Event on a Local Government Area, Region, State or Territory", in: Valuing Tourism: methods and techniques. Bureau of Tourism research Occasional, 28, Canberra.

O'Neill, J. (2001). Building better global economic BRICs. Global Economics, 66. Available at: http://www.goldmansachs.com/korea/ideas/brics/building-better-pdf.pdf

Oppermann, M. (1996). "Convention cities: Images and changing fortunes". Journal of tourism studies, 7(1), 10.

Pacaud, L., Vollet, D., and Angeon, V. (2007). "Impact of tourism infrastructure on regional development: the implantation of a Center Parcs resort in northern France". Tourism Economics, 13(3), 389-406.

Pinson, J. (2016). "Heritage sporting events: theoretical development and configurations". Journal of Sport \& Tourism, 21(2), 133-152.

Preuss, H. (2007). "The conceptualisation and measurement of mega sport event legacies". Journal of sport \& tourism, 12(3-4), 207-228.

Qu, H., Li, L., and Chu, G. K. T. (2000). "The comparative analysis of Hong Kong as an international conference destination in Southeast Asia". Tourism Management, 21(6), 643-648.

Ritchie, J. R. B., and Crouch, G. I. (1997). "Roles and contributions to destination competitiveness", in 47 Congress of the Association International d'Experts Scientifiques $d u$ Tourisme.

Roche, M. (2000). "Mega-events and modernity". London: Routledge, pp. 1-30.

Schimmel, K. S. (2006). "Deep Play: sports mega-events and urban social conditions in the USA", in: Horne, J. and Manzenreiter, W. (Ed.) Sports Mega-Events: Social Scientific Analyses of a Global Phenomenon. (Special Issue: The Sociological Review Monograph Series), 54(s2), pp. 160-174.

Siegfried, J., and Zimbalist, A. (2000). "The economics of sports facilities and their communities". Journal of Economic Perspectives, 14(3), 95-114.

Solberg, H. A., and Preuss, H. (2007). "Major sport events and long-term tourism impacts". Journal of sport Management, 21(2), 213-234.

Tanford, S., Montgomery, R., and Nelson, K. B. (2012). "Factors that influence attendance, satisfaction, and loyalty for conventions". In Journal of Convention \& Event Tourism, 13(4), 290-318.

Treasury, N. S. W. (1997). The economic impact of the Sydney Olympic games. The Centre for Regional Economic Analysis University of Tasmania. (Office of Financial Management Research and Information Paper.) http://www.treasury.nsw.gov.au/pubs/trp97 10/ index.htm.

Thomson, A., Cuskelly, G., Toohey, K. Kennelly, M., Burton, P., Fredline, L. (2018). Sport event legacy: A systematic quantitative review of literature. Sport Management Review. Article in Press. 
Wan, Y. K. P. (2011). "Assessing the strengths and weaknesses of Macao as an attractive meeting and convention destination: Perspectives of key informants". Journal of Convention \& Event Tourism, 12(2), 129-151.

WEF - World Economic Forum (2007). The Travel \& Tourism Competitiveness Report 2007. Available in: <http://www.weforum.org/>. Acess in: 12 de mar de 2016.

WEF - World Economic Forum. (2015). The Travel \& Tourism Competitiveness Report 2015. Available in: <http://www.weforum.org/>. Acess in: 12 de mar de 2016.

Wong, I. A. (2011). Using destination attributes to promote event travel: The case of Macau. Journal of Convention \& Event Tourism, 12(4), 241-252. 